J. Clin. Chem. Clin. Biochem.

Vol. 18, 1980, pp. 157-162

\title{
An Improved Method for Routine Analysis of Polyamines in Biological Fluids with a Conventional Amino Acid Analyzer
}

\author{
By G. Milano, M. Schneider, P. Cambon, J. L. Boublil, J. Barbe, N. Renee and C. M. Lalanne \\ Centre Antoine-Lacassagne, 36 Voie Romaine, 06054 Nice Cedex, France
}

(Received July 9/October 1,1979 )

Summary: An accurate and precise mechanized ion-exchange chromatographic method for the estimation of polyamines in biological fluids is described. The method includes the recent improvements developed for ion-exchange analysis of polyamines: the use of sulfonated polystyrene cation-exchange resin with a bead diameter of less than $10 \mu \mathrm{m}$ and a continuous fluorescent detection with $o$-phthalaldehyde.

Four different procedures for the removal of protein before analysis of polyamines in plasma have been compared. Linearity of the fluorescence detection, reproducibility (intra, inter assay) and precision of the retention times are reported.

Furthermore, the method is characterised by the simplicity of the sample preparation, a clear and rapid elution programme and especially by its routine applicability, as shown during the last six months in the Centre AntoineLacassagne.

\section{Verbesserte Methode zur Routine-Bestimmung von Polyaminen in biologischen Flüssigkeiten mit einem konventionellen Aminosäure-Analysator}

Zusammenfassung: Eine richtige und genaue mechanisierte ionenaustauschchromatographische Methode zur Bestimmung von Polyaminen in biologischen Flüssigkeiten wird beschrieben. Die Methode berücksichtigt neuere Verbesserungen, die für die Ionenaustauschchromatographie von Polyaminen entwickelt wurden: die Verwendung von sulfoniertem Polystyrol-Kationenaustauscher-Harż mit einem Perlendurchmesser $<10 \mu \mathrm{m}$ und kontinuierliche Fluoreszenz-Detektion mit $o$-Phthalaldehyd.

Vier verschiedene Methoden zur Enteiweißung vor der Bestimmung von Polyaminen in Plasma wurden verglichen. Die Linearität der Fluoreszenz-Detektion, die Reproduzierbarkeit (in Serie, von Tag zu Tag) und die Präzision der Retentionszeit werden mitgeteilt.

Die Methode ist ferner charakterisiert durch einfache Probenvorbereitung, ein kleines und schnelles Elutionsprogramm und besonders die Anwendbarkeit in der Routine, wie während der letzten sechs Monate im Centre AntoineLacassagne gezeigt wurde.

\section{Introduction}

During the last decade, polyamines, especially putrescine $\left(\mathrm{NH}_{2}-\left(\mathrm{CH}_{2}\right)_{4}-\mathrm{NH}_{2}\right)$ and spermidine $\left(\mathrm{NH}_{2}-\left(\mathrm{CH}_{2}\right)_{3}-\mathrm{NH}-\right.$ $\left.\left(\mathrm{CH}_{2}\right)_{3}-\mathrm{NH}_{2}\right)$, have attracted the attention of scientists and clinicians, owing to their implication in growth process and their association with cancer $(1-11)$. Therefore, development of analytical methods for the evaluation of polyamines in biological fluids has made considerable progress and it appears that methods using thin layer chromatography of dansylated polyamines $(12,13)$, mechanized ion-exchange chromatography
$(14,15)$ and high pressure liquid chromatography $(16$, 17) are specific and sensitive enough to quantify polyamines in urine or plasma. But there is a growing interest in polyamines in relation to cancer; levels of putrescine may be related to the proliferation of malignant cells, and measurement of spermidine permits a short term evaluation of the efficiency of treatment (4). Thus an increasing number of samples is submitted for day to day analysis.

This paper describes a fully adapted method for routine analysis of polyamines in plasma or urine based on the 
principle of mechanized ion-exchange chromatography with continuous fluorescence detection $\left(\lambda_{\mathrm{ex}}=350 \mathrm{~nm}\right.$, $\lambda_{\text {em }}=440 \mathrm{~nm}$ ).

Conditions were chosen so that the retention times of putrescine, spermidine and spermine were $28 \mathrm{~min}$, $37 \mathrm{~min}$ and $45 \mathrm{~min}$ respectively; these values are in the range of those obtained by high performance liquid chromatography as recently described by Seiler (16). With the present method, there is the double advantage that tedious extraction procedures are avoided and complete adaptation of the method for routine purposes is possible, as proved by the thousand urine analyses performed during the last six months.

\section{Material and Methods \\ Standard solutions}

Putrescine, cadaverine, spermidine, spermine were obtained in the form of hydrochloride salts, from SIGMA France. Internal standard, 4-azaheptamethylenediamine was obtained from MERCK.

Standard working solution was made in $0.1 \mathrm{~mol} / 1 \mathrm{HCl}$ with putrescine $25 \mu \mathrm{mol} / 1$, cadaverine $25 \mu \mathrm{mol} / \mathrm{l}$, spermidine $25 \mu \mathrm{mol} / 1$, spermine $25 \mu \mathrm{mol} / 1$ and internal standard $20 \mu \mathrm{mol} / \mathrm{l}$.

Standard solutions were stable at $-20^{\circ} \mathrm{C}$ during $1-2$ months or at $4^{\circ} \mathrm{C}$ during one week without any degradation.

\section{Elution buffers}

Sodium citrate buffers as described by Villanueva (18) with some modifications: Buffer A pH 5.50 Trisodium-citrate $0.2 \mathrm{~mol} / 1, \mathrm{NaCl} 1.0 \mathrm{~mol} / 1$. Buffer B pH 5.70 Trisodiumcitrate $0.2 \mathrm{~mol} / 1, \mathrm{NaCl} 2.6 \mathrm{~mol} / \mathrm{l}$.

Buffers A and B were filtered through Millipore filters (GS $0.22 \mu \mathrm{m}$ ). Forty $\mathrm{ml}$ of absolute ethanol were added to one liter of the buffer A and fifty $\mathrm{ml}$ to one liter of the buffer B. The $\mathrm{pH}$ was adjusted with concentrated $\mathrm{HCl}$ after the addition of ethanol.

\section{Resin regeneration buffer}

$\mathrm{NaOH} 0.2 \mathrm{~mol} / 1$.

\section{Fluorescence buffer}

One liter of potassium borate buffer $\mathrm{pH} 10.4,0.4 \mathrm{~mol} / 1$ was prepared as follows: $25 \mathrm{~g}$ of boric acid were dissolved in approximatively $950 \mathrm{ml}$ of bi-distilled water and $\mathrm{pH}$ adjusted with a $500 \mathrm{~g} / \mathrm{l}$ solution of potassium hydroxide.

The solution was filtered through a Millipore filter (GS $0.22 \mu \mathrm{m}$ ). Three $\mathrm{ml}$ of BRIJ-35 30\% (TECHNICON) were dissolved in the filtered solution.

Just before use and for ten analyses, the reagent solution was prepared by mixing $200 \mathrm{mg}$ of o-phthalaldehyde (FLUKA) with $2.5 \mathrm{ml}$ of absolute ethanol and $0.5 \mathrm{ml}$ of 2-mercaptoethanol as previously described (19). After mixing on a vortex, the mixture was added with magnetic stirring to $250 \mathrm{ml}$ of the fluorescence buffer.

\section{Apparatus}

Analyses were performed with a Kontron LIQUIMAT III aminoacid analyzer equipped with a $350 \times 4 \mathrm{~mm}$ column filled with a Durrum DC4A cation exchange resin. The basic equipment included two Labotron HKP pumps.with pistons and ball valves in sapphire and ruby respectively, and one selector valve which controlled the selected buffer flow to the pump. Column temperature was controlled by a circulating water thermostat, type SK 58 (HAAKE Co, Berlin). Continuous fluorescent detection was by an UV detector type UDC/F with a G.E mercury lamp type F4 T4 BL equipped with a primary filter at $35 \mathrm{Q} \mathrm{nm}$ and a Wratten $2 \mathrm{~A}$ secondary filter at $\mathbf{4 4 0} \mathrm{nm}$ and a $50 \mu \mathrm{l}$ cell.
All the steps were controlled by a programmer including a microprocessor. Operations in manual mode were also possible. Samples were injected by means of an automatic injector (8 samples), or manually.

\section{Urine assay procedure}

Twentyfour hour urine specimens were collected in glass bottles containing $10 \mathrm{ml}$ of concentrated $\mathrm{HCl}$ and kept refrigerated $\left(4^{\circ} \mathrm{C}\right)$ during the time of collection.

The volume of urine was determined and an aliquot (approx. $5 \mathrm{ml}$ ) from each collection was stored at $-20^{\circ} \mathrm{C}$ until the anaiysis was performed. The aliquot was filtered through a millipore filter type MILLEX $(0.22 \mu \mathrm{m})$ MILLIPORE. $2 \mathrm{ml}$ of the filtered urine were treated as follows: $\overline{50} \mathrm{mg}$ of sulfosalicylic acid and $125 \mu \mathrm{l}$ of internal standard $(0.2 \mathrm{mmol} / 1$ in $0.1 \mathrm{~mol} / 1$ $\mathrm{HCl}$ ) were added, then the mixture was shaken, left $15 \mathrm{~min}$ at room temperature and centrifuged $3000 \mathrm{~g}, 15 \mathrm{~min}, 5^{\circ} \mathrm{C}$. To $1 \mathrm{ml}$ of the supernatant was added $1 \mathrm{ml}$ of concentrated $\mathrm{HCl}$ in order to obtain a final concentration of $6 \mathrm{~mol} / 1 \mathrm{HCl}$.

The acidified sample was submitted to hydrolysis during 14 to 16 hours at $110^{\circ} \mathrm{C}$ followed by centrifugation $3000 \mathrm{~g}, 20 \mathrm{~min}$, $4^{\circ} \mathrm{C} .1 \mathrm{ml}$ of the supernatant was transferred and evaporated on a BUCHI-rotavapor- $R$. The dried residue was reconstituted in $300 \mu \mathrm{l}$ of $0.1 \mathrm{~mol} / 1 \mathrm{HCl}$ and $30 \mu \mathrm{l}$ were loaded on the automatic injector.

\section{Plasma assay procedure}

We compared several of the known procedures for removing protein from plasma before polyamine analysis by ion-exchange chromatography: 1) $250 \mathrm{~g} / 1$ sulfosalicylic acid, 2) $200 \mathrm{~g} / 1$ trichloroacetic acid, 3) $200 \mathrm{~g} / 1$ trichloroacetic acid followed by diethyl ether treatment of the supernatent, 4) $1.2 \mathrm{~mol} / 1$ perchloric acid.

A similar study has been done with tissue (rat spleen) in comparing the same extraction procedures (27). The authors noted unexpected higher polyamine values with trichloroacetic acid followed by ether extraction, than those found with the other procedures.

In plasma assays, there are small differences between the four procedures (tab. 1). In our hands, ether extraction after tri-

Tab. 1. Comparison of procedures for protein removal before ion-exchange analysis of polyamines. $3 \mathrm{ml}$ of a pool of plasma from patients with cancer were treated in duplicate with different precipitating agents. Experimental conditions in Material and Methods.

\begin{tabular}{|c|c|c|c|c|c|}
\hline $\begin{array}{l}\text { Procedure for } \\
\text { protein } \\
\text { precipitation }\end{array}$ & $\begin{array}{l}\text { Special } \\
\text { conditions } \\
\text { during } \\
\text { precipitation }\end{array}$ & $\begin{array}{l}\text { Putresc } \\
\text { (umol/l }\end{array}$ & $\begin{array}{l}\text { cine } \\
\text { mean }\end{array}$ & $\begin{array}{l}\text { Spern } \\
\text { (umo }\end{array}$ & $\begin{array}{l}\text { nidine } \\
\text { 1/1) } \\
\text { mean }\end{array}$ \\
\hline $\begin{array}{l}250 \mathrm{~g} / 1 \\
\text { Sulfosalicylic acid }\end{array}$ & $\begin{array}{l}70^{\circ} \mathrm{C} \\
30 \mathrm{~min}\end{array}$ & $\begin{array}{l}13.60 \\
13.80\end{array}$ & 13.70 & $\begin{array}{l}0.75 \\
1.13\end{array}$ & 0.94 \\
\hline $\begin{array}{l}200 \mathrm{~g} / 1 \\
\text { Trichloroacetic } \\
\text { acid }\end{array}$ & $\begin{array}{c}0^{\circ} \mathrm{C} \\
30 \mathrm{~min} \\
.\end{array}$ & $\begin{array}{l}11.90 \\
12.30\end{array}$ & 12.10 & $\begin{array}{l}0.73 \\
0.83\end{array}$ & 0.78 \\
\hline $\begin{array}{l}200 \mathrm{~g} / 1 \\
\text { Trichloroacetic } \\
\text { acid }\end{array}$ & $\begin{array}{c}0^{\circ} \mathrm{C} \\
30 \mathrm{~min}\end{array}$ & & & & \\
\hline $\begin{array}{l}\text { Supernatant } \\
\text { extracted twice with } \\
\text { diethyl ether } \\
\text { (volume/volume) }\end{array}$ & & $\begin{array}{l}12.10 \\
12.40\end{array}$ & 12.25 & $\begin{array}{l}0.76 \\
0.85\end{array}$ & 0.81 \\
\hline $\begin{array}{l}1.2 \mathrm{~mol} / 1 \\
\text { Perchloric acid }\end{array}$ & $\begin{array}{l}\text { Room } \\
\text { temperature } \\
30 \mathrm{~min}\end{array}$ & $\begin{array}{l}11.00 \\
11.10\end{array}$ & 11.05 & $\begin{array}{l}0.92 \\
1.00\end{array}$ & 0.96 \\
\hline
\end{tabular}


chloroacetic acid treatment do not cause a significant increase in the polyamine content. Furthermore, it appears that $250 \mathrm{~g} / 1$ sulfosalicylic acid treatment results in the highest polyamine measurements. Thus, we decided to adopt the following process for routine analysis of polyamines in plasma:

$10 \mathrm{ml}$ of venous blood were collected on sodium heparinate $0.1 \mathrm{~g} / \mathrm{l}$ and cellular separation was immediately performed by centrifugation $2000 \mathrm{~g}, 10 \mathrm{~min}$. Plasma was immediately stored at $-20^{\circ} \mathrm{C}$ until analysis. To a $3 \mathrm{ml}$ sample of plasma were added $25 \mu \mathrm{l}$ of internal standard $(0.2 \mathrm{mmol} / 1$ in $0.1 \mathrm{~mol} / 1 \mathrm{HCl}) ; 500 \mu \mathrm{l}$ of $250 \mathrm{~g} / \mathrm{l}$ aqueous sulfosalicylic acid were added under vortex mixing. The proteins were allowed to precipitate for $30 \mathrm{~min}$ at $70^{\circ} \mathrm{C}$. The sample was centrifuged $\left(3000 \mathrm{~g}, 20 \mathrm{~min}, 4^{\circ} \mathrm{C}\right)$, the supernatant decanted, the pellet resuspended in $500 \mu \mathrm{l}$ of $250 \mathrm{~g} / 1$ aqueous sulfosalicylic acid, recentrifuged and the supernatant added to the previous one. The total supernatant was evaporated on a Büchi-Rotavapor-R. The residue was reconstituted in $1 \mathrm{ml}$ of $6 \mathrm{~mol} / 1 \mathrm{HCl}$ and hydrolysed 14-16 hours at $110^{\circ} \mathrm{C}$. After hydrolysis the sample was centrifuged and the supernatant evaporated in the same conditions. The final dried residue was reconstituted in $200 \mu \mathrm{l}$ of $0.1 \mathrm{~mol} / 1 \mathrm{HCl}$ and shaken 2-3 $\mathrm{min}$ in a.60 $60^{\circ} \mathrm{C}$ water bath for complete dissolution. $\mathrm{A}$ $30 \mu \mathrm{l}$ aliquot was loaded on the analyzer.

\section{Experimental conditions}

The resin column length was $80 \mathrm{~mm}$, ID $4 \mathrm{~mm}$, with a column temperature of $67^{\circ} \mathrm{C}$. Flow rates for buffers and reagent were respectively $22.5 \mathrm{ml}$ per hour and $24 \mathrm{ml}$ per hour.

\section{Elution procedure}

Table 2 summarises the different steps for 8 complete analyses with the automatic injector.

The function "pressure cut off" is employed for a momentary interruption of the safety pressure control which switches off the analysis when pressure exceeds low or high fixed limits (5-95 bars). The maximum of the column pressure during the normal course of elution was in the range of 45-75 bars. The functions of 19 and 20 allow the automatic sample injector to move forward one sample; therefore, steps 00 and 06 bring on respectively one rotation of the injector to the next loop. During the steps 04 and 10 resin is regenerated with $0.2 \mathrm{~mol} / 1 \mathrm{NaOH}$ and steps 05 and 11 allow equilibration with the first buffer. The function "repeat" subtracts one unit from the number of cycles at the end of each cycle.

\section{Calculations}

The satisfactory stability of the baseline and the straightness of the peaks made it possible to evaluate the concentration of different polyamines by measuring the peak hights. For each individual sample, recovery was determined by the means of the internal standard and this value corrected the final concentration of each polyamine. Recoveries usually ranged from $80 \%$ to $90 \%$ for urine. Over 150 analyses the mean recovery was $82 \%$ with a coefficient of variation of $10.8 \%$. However, lower recoveries were observed with plasma $(60-85 \%)$. This material loss was the consequence of the total removal of protein, which was necessary for keeping the resin free of contamination, and to avoid increasing the pressure of the column with a resulting unsatisfactory resolution.

\section{Comments on the method}

- Water used for buffer preparation must be deionized and doubly distilled. Buffer solutions are stocked in brown bottles and kept under refrigeration.

- Adjustement of the $\mathrm{pH}$ of the buffers must be made to within 0.02 . Uncorrected $\mathrm{pH}$ values, especially for the second buffer, results in a decreased resolution of the respective peaks of polyamines.

- The conditions of evaporation of samples must be correctly evaluated. We found that an increased water bath temperature (over $45^{\circ} \mathrm{C}$ ) and a longer duration of drying (over $10 \mathrm{~min}$ ) may lead to a loss of polyamines, putrescine being particularly affected.

- As previously indicated, removal of proteins from urine and from plasma must be performed carefully because the presence of proteins in the samples injected leads to an increased pressure in the column and may necessitate removal of the resin. Also the presence of precipitates of any form in the sample will also obviously lead to a blockage of the resin bed sooner or later. They should therefore be removed using either centrifugation or filtration.

\section{Results}

A linear fluorescence response was observed for polyamine concentrations from $12.5 \mu \mathrm{mol} / 1$ to $250 \mu \mathrm{mol} / 1$ under our routine conditions. The limit of sensitivity was reached in the range of 10 pmoles injected.

Tab. 2. Polyamine analysis programme with a KONTRON LIQUIMAT III automated ion-exchange chromatograph. Total run time 73 min $35 \mathrm{~s}$.

\begin{tabular}{|c|c|c|c|c|c|c|c|c|c|c|c|c|c|c|c|}
\hline \multirow[t]{2}{*}{ Step } & \multirow[t]{2}{*}{$\begin{array}{l}\text { Time } \\
\text { min }\end{array}$} & \multirow[t]{2}{*}{$\dot{\mathbf{s}}$} & \multirow[t]{2}{*}{$\begin{array}{l}\text { Num- } \\
\text { ber } \\
\text { of cy- } \\
\text { clès }\end{array}$} & \multicolumn{2}{|c|}{ Functions } & \multirow[b]{2}{*}{$\begin{array}{l}\text { Buffer } \\
\text { B }\end{array}$} & \multirow[b]{2}{*}{$\begin{array}{l}\mathrm{NaOH} \\
0.2 \\
\text { mol/1 } \\
\text { regen- } \\
\text { eration } \\
\end{array}$} & \multirow[b]{2}{*}{$\begin{array}{l}\text { Detec- } \\
\text { tor }\end{array}$} & \multirow[b]{2}{*}{$\begin{array}{l}\text { Buffer } \\
\text { pump }\end{array}$} & \multirow[b]{2}{*}{$\begin{array}{l}\text { Rea- } \\
\text { gent } \\
\text { pump }\end{array}$} & \multirow[b]{2}{*}{$\begin{array}{l}\overline{R e}- \\
\text { corder }\end{array}$} & \multirow[b]{2}{*}{$\begin{array}{l}\text { Auto- } \\
\text { matic } \\
19 \text { In- } \\
\text { jector }\end{array}$} & \multirow[b]{2}{*}{$\begin{array}{l}\text { Auto- } \\
\text { matic } \\
20 \text { In- } \\
\text { jector }\end{array}$} & \multirow[b]{2}{*}{$\begin{array}{l}\text { Tem- } \\
\text { pera- } \\
\text { ture } \\
67^{\circ} \mathrm{C}\end{array}$} & \multirow[b]{2}{*}{$\begin{array}{l}\text { Pressure } \\
\text { cut off }\end{array}$} \\
\hline & & & & Repeat & $\begin{array}{l}\text { Buffer } \\
\dot{A}\end{array}$ & & & & & & & & & & \\
\hline $\begin{array}{l}00 \\
01 \\
02 \\
03 \\
04 \\
05 \\
06 \\
07 \\
08 \\
09 \\
10 \\
11 \\
12\end{array}$ & $\begin{array}{l}00 \\
00 \\
20 \\
25 \\
08 \\
20 \\
00 \\
00 \\
20 \\
25 \\
08 \\
20\end{array}$ & $\begin{array}{l}05 \\
30 \\
00 \\
00 \\
00 \\
00 \\
05 \\
30 \\
00 \\
00 \\
00 \\
00\end{array}$ & 04 & $\dot{\mathbf{x}}$ & $\begin{array}{l}\mathbf{X} \\
\ddot{\mathbf{X}} \\
\mathbf{X} \\
\mathbf{X}\end{array}$ & $\mathbf{x}$ & $\mathbf{x}$ & 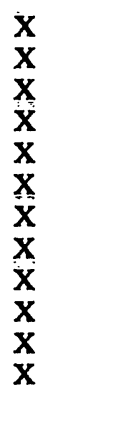 & $\begin{array}{l}\mathbf{X} \\
\mathbf{X} \\
\mathbf{X} \\
\mathbf{X} \\
\mathbf{X} \\
\\
\mathbf{X} \\
\mathbf{X} \\
\mathbf{X} \\
\mathbf{X} \\
\mathbf{X} \\
\mathbf{X}\end{array}$ & $\begin{array}{l}\mathbf{X} \\
\mathbf{X} \\
\mathbf{X}\end{array}$ & $\begin{array}{l}\mathbf{x} \\
\mathbf{X} \\
\mathbf{X} \\
\mathbf{x}\end{array}$ & $\mathbf{x}$ & $\mathbf{X}$ & $\begin{array}{l}\mathbf{X} \\
\mathbf{X} \\
\mathbf{X} \\
\mathbf{X} \\
\mathbf{X} \\
\mathbf{X} \\
\mathbf{X} \\
\mathbf{X} \\
\mathbf{X} \\
\mathbf{X} \\
\mathbf{X} \\
\mathbf{X}\end{array}$ & $\begin{array}{l}\mathbf{X} \\
\mathbf{X}\end{array}$ \\
\hline
\end{tabular}




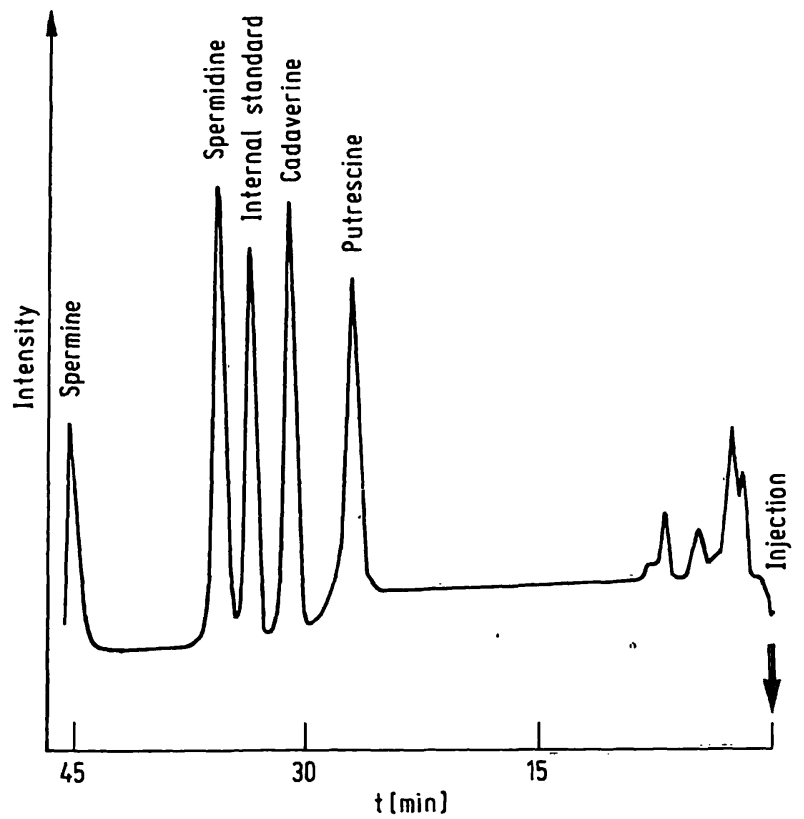

Fig. 1. Chromatogram of calibration mixture of polyamines. Sample concentrations: putrescine, $25 \mu \mathrm{mol} / 1$; cadaverine $25 \mu \mathrm{mol} / \mathrm{l}$; spermidine $25 \mu \mathrm{mol} / 1$; spermine $25 \mu \mathrm{mol} / 1$ and internal standard $20 \mu \mathrm{mol} / 1$. Injection $30 \mu \mathrm{l}$. Experimental conditions in Material and Methods.

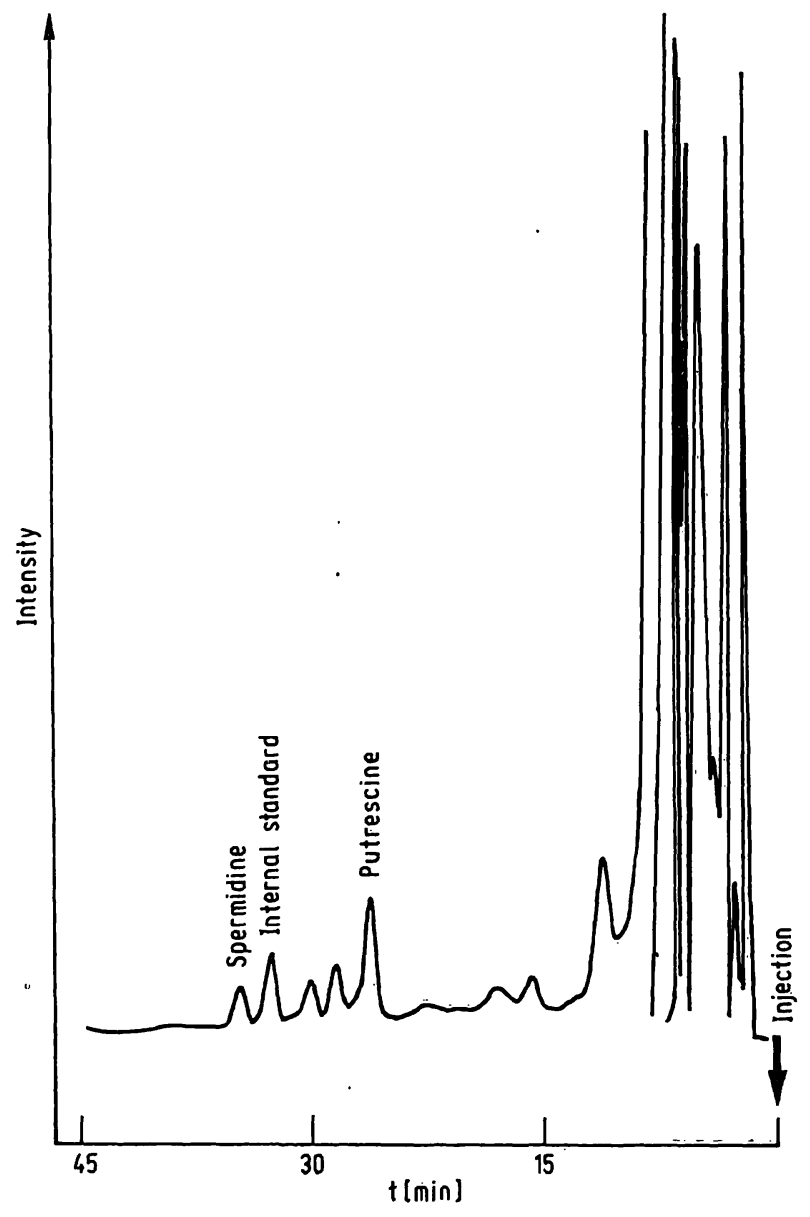

Fig. 2. Polyamine chromatogram of a 24 hour urine sample. Healthy control. Experimental conditions in Material and Methods.
Tab. 3. Precision of retentiön time for polyamines. ( $n=17$ standard solutions; $\bar{x}=$ mean; $s=$ standard deviation; $\left.\operatorname{CV}(\%)=\frac{s}{\bar{x}} \times 100\right)$.

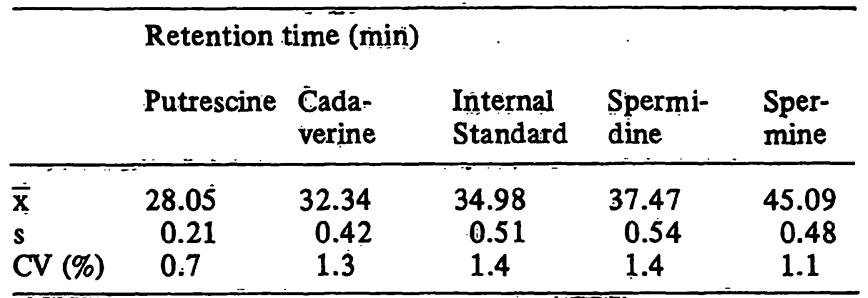

Reproducibility was evaluated with replicate analyses of a pooled urine, coefficients of variation were putrescine $2.8 \%$, spermidine $0.8 \%$ for intraassay reproducibility (seven identical samples in the same series), and putrescine $4.5 \%$, spermidine $5.0 \%$ for interassay reproducibility (one identical sample in seven different series).

Figure 1 shows separation, resolution and order of elution of polyamines in a standard mixture. Table 3 illustrates the excellent precision in retention times with this instrumentation and the present chromatographic conditions.

Figures 2 and 3 represent, respectively, urinary polyamine profiles in a healthy individual and in a patient

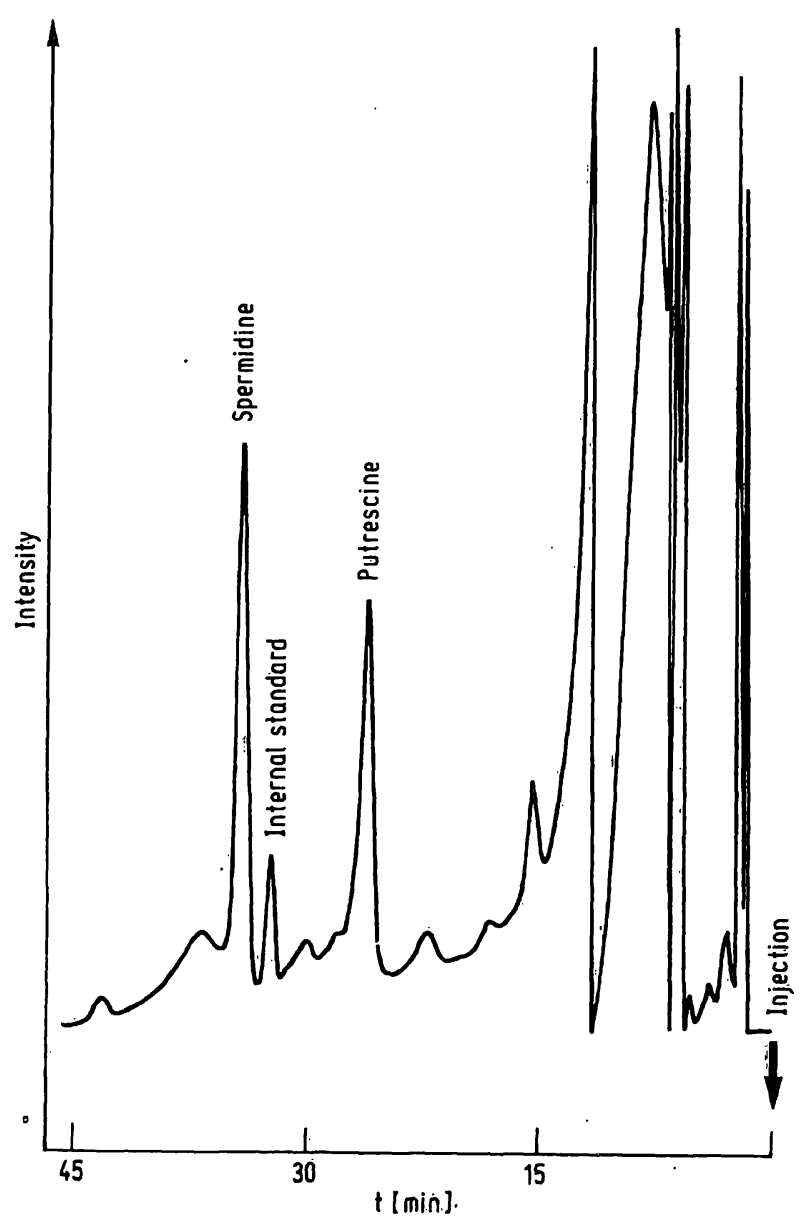

Fig. 3. Polyamine chromatogram of a 24 hour urine sample. Patient with cancer. Experimental conditions in Material and Methòds. 


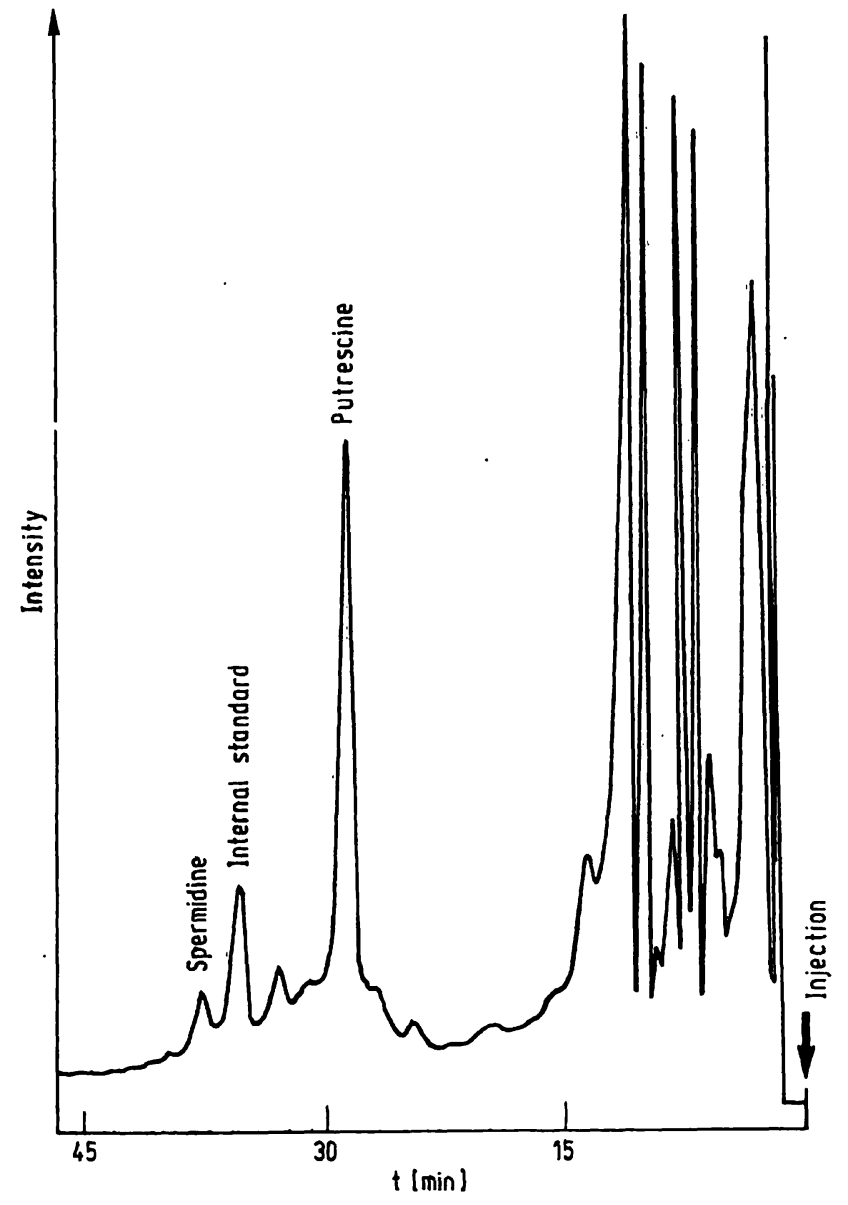

Fig. 4. Polyamine chromatogram of a pooled plasma. Experimental conditions in Material and Methods.

with cancer. Polyamines in a pool of plasma are represented in figure 4. Plasma is prefered to serum because polyamines have been described as being absorbed to the membrane of blood cells (20), so that during serum clotting their dissemination is possible and may lead to their overestimation.

A detailed clinical study is in press (21). From 22 normal individuals ( 14 males, 8 females) the upper limits for urinary polyamines have been fixed at $(m+2 \sigma)$ : putrescine $2.00 \mu \mathrm{g} / \mathrm{mg}$ creatinine and spermidine $1.60 \mu \mathrm{g} / \mathrm{mg}$ creatinine. Spermine and cadaverine are not mentioned here, because they provide no extra information, compared with demonstrated clinical usefulness of putrescine and spermidine in cancer (4).

\section{Discussion}

Polyamines have attracted the interest of many workers in basic molecular biology, and in clinical applied cancer research $(1-3,22)$. Different methods for a quantitative measurement of polyamines in biological fluids are now available. At the present time, high performance liquid chromatography (HPLC) draws particular attention and several applications have been recently described for polyamines $(16,17)$. In terms of rapidity and sensitivity, it seems that HPLC represents an advance in polyamine analysis, but its routine applicability has not been yet fully demonstrated; biological samples must of ten be pre-extracted (16), or even prepurified (17).

Immunological methods have been also described (23, $24)$, and radioimmunoassays established $(25,26)$ but the lack of specificity of antibodies is not compatible with reliable clinical exploitation.

As mentioned by Seiler (27) automated ion-exchange chromatography has been largely explored, and has generated many analytical applications for polyamines. The present work describes a method which represents an advantageous alternative to more sophisticated forms of polyamine analysis, such as automated high pressure ion-exchange chromatography (28). The utilization of small resin particles with a diameter of $8 \mu \mathrm{m}$ and a continuous fluorescence detection with $o$-phthalaldehyde reduces the elution time of each polyamine and insures a sensitivity in the range of $10^{-11}$ moles.

Furthermore simplified sample and buffer preparations associated with an easy handling of the apparatus allow a non specialized staff to perform day to day polyamine determinations in biological fluids. Thus it appears this method may provide a useful tool in support of research for bio-markers in cancer.

\section{Acknowledgements}

We thank Dr. $V$. Villanueva (CNRS, Gif sur Yvette, France) for his useful contribution.

We thank Mr. B. Fontaine for his excellent assistance in the preparation of photographs.

\section{References}

1. Russel, D. H. (1973), in Polyamines in normal and neoplastic growth (Russel, D. H. ed.), Raven Press, New York.

2. Campbell, R. A., Morris, D. R., Bartos, D., Daves, G. D. \& Bartos, F. (1978), in Advances in polyamines research (Campbell, R. A., Morris, D. R., Bartos, D., Daves, G. D. \& Bartos, F. eds.), Vól. 1, Raven Press, New York.

3. Campbell, R. A., Morris, D. R., Bartos, D., Daves, G. D. \& Bartos, F. (1978), in Advances in polyamines research (Campbell, R. A., Morris, D. R., Bartos, D., Daves, G. D. \& Bartos, F., eds.), Vol. 2, Raven Press, New York.
4. Durie, B. G. M., Salmon, S. E. \& Russel, D. H. (1977), Cancer Res. 37, 214-221.

5. Lipton, A., Sheeman, L. \& Kessler, G. F. (1975), Cancer $35,464-468$.

6. Lipton, A., Sheeman, L. \& Harvey, H. A. (1975), Cancer 36, 2351-2354.

7. Lipton, A., Sheeman, L., Mortel, R. \& Harvey, H. A. (1976), Cancer 38, 1344-1347.

8. Russel, D. H., Durie, B. G. M. \& Salmon, S. E. (1975), Lancet II, 797-800. 
9. Russel, D. H. (1977), Clin. Chem. 23, 22-27.

10. Cohen, S. S. (1977), Cancer Res. 37, 939-942.

11. Fujita, K., Nagatsu, T., Maruta, K., Ito, M., Semba, H. \& Miki, K. (1976), Cancer Res. 36, 1320-1324.

12. Fleisher, J. H. \& Russel, D. H. (1975), J. Chromatogr. 110, $335-340$.

13. Heby, O. \& Andersson, G. (1978), J. Chromatography, Biomedical Application 145, 73-80.

14. Marton, L. J., Russel, D. H. \& Levy, C. C. (1973), Clin. Chem. $19,923-926$.

15. Gehrke, C. N., Kuo, K. C. \& Ellis, R. L. (1977), J. Chromatography, Biomedical Application 143, 345-361.

16. Seiler, N. \& Khödges, B. (1978), J. Chromatography, Biomedical Application 145, 29-39.

17. Hayashi, T., Sugiura, T., Kawai, S. \& Ohno, T. (1978), J. Chromatography Biomedical Application 145, 141-146.

18. Villanueva, V. R. \& Adlakha, R. C. (1978), Ann. Biochem. 91, 264-275.

19. Marton, L. J. \& Lee, P. L. Y. (1975), Clin. Chem. 21, 1721-1724.

20. Cooper, K. D., Shukla, J. B. \& Rennert, O. M. (1978), Clin. Chim. Acta 82, 1-7.
21. Milano, G., Schneider, M., Viguier, E., Cassuito, P., Namer, M., Boublil, J. L., Cambon, P. \& Lalanne, C. M. (1979), Përgamon Press, in Press.

22. Jậnine, J., Pösö, H. \& Raina, A. (197.8), Biochim. Biophys. Acta 473, 241-293.

23. Quash, G., Gresland, L., Delain, E. \& Huppert, J. (1973), in Polyamines in normal and neoplastic growth (Russel, D. H. ed.) 157-167, Raven Press, New York.

24. Bonnefoy-Roch, A. M. \& Quash, G. (1978), in Advanced in polyaminines research (Campbell, R. A., Morris, D. R., Bartos, D., Daves, G. D. \& Bartoș, F.; eds.) Vol. 2, 55-65, Raven Press, New York.

25. Bartoș, D., Campbell, R. A., Bartớs, F. \& Grettie, D. P. (1975), Cancer Res. 35, 2056-2060.

26. Bartos, F., Bartos, D., Grettie, D. P., Campbell, R. A., Marton, L. J., Smith, R. G. \& Daves, G. D. (1977), Biochem. Biophys. Res. Commun. 75, 915-919.

27. Seiler, N. (1977), J. Chromatography, Biomedical Application 143, 221-246.

28. Marton, L., Heby, O. \& Wilson, C. (1974), FEBS letters 41, 99-103.

Centre Antoine-Lacassagne, 36 Voie Romaine F-06054 Nice Cedex 